\title{
Relation between diet composition and coronary heart disease risk factors
}

\author{
M Porrini, P Simonetti, G Testolin, C Roggi, M S Laddomada, M T Tenconi
}

\begin{abstract}
Study objective-The aim was to evaluate dietary intakes and their correlation to some risk factors for coronary heart disease.

Design-The study was a population based survey with random sample selection stratified by age and sex.

Participants -352 adults living in a small town in Northern Italy took part in the study. Response rate was $46 \%$ among females and $48 \%$ among males. Refusal to take part was mainly due to the large number of tests involved.

Measurements and main results-Diets were high in protein (animal/vegetable ratio 1.7 in women and 1.4 in men) and in fat and low in carbohydrates. The hypercholesterolaemic and atherogenic potential of the diet, evaluated by the cholesterol/saturated fat index, was high in about $50 \%$ of the population. The thiamin and riboflavin intakes were lower than the Italian recommended allowances in more than $60 \%$ of the people tested, whereas the vitamin $A$ intake was more than adequate in about $70 \%$. A positive association was found in the younger groups (men and women 20-39 years old) between some nutrient components (energy, alcohol, total and saturated fats) and some blood lipids. In the older people blood lipids were correlated with body mass index.

Conclusions-The overall data indicate that a correlation exists between dietary intake and some risk factors for coronary heart disease; dietary intervention, at least in young adults, is suggested.
\end{abstract}

Dipartimento di

Scienze e Tecnologie

Alimentari e

Microbiologiche,

Sezione Nutrizione,

University of Milan

Via Celoria 2, 20133

Milan, Italy

M Porrini

P Simonetti

G Testolin

Dipartimento di

Medicina Preventiva,

Occupazionale e di

Communitá, Sezione

di Igiene, University

of Pavia, Pavia, Italy

C Roggi

M S Laddomada

M T Tenconi

Correspondence to: Dr Porrini

Accepted for publication August 1990
Previous publications have shown that food habits and dietary intake are foremost among the factors that influence the risk of coronary heart disease. However the specific dietary components responsible for that risk are still poorly understood.

The association between blood lipids and coronary heart disease has been known for some time, ${ }^{1-3}$ so it is possible that the diet could influence the disease through its effect on blood lipids. For this reason it could be important for the prevention of this disease to study the dietary habits and lipid profile of specific groups of the population.

Our aim was to study the distribution of some of the risk factors for coronary heart disease and to correlate these factors with diet composition. The study was carried out on a random sample of adults living in Northern Italy.
Methods

SUBJECTS

The study on the correlation between diet and cardiovascular disease risk factors was conducted on 352 adults ( 166 men and 186 women) living in Northern Italy (Casteggio, PV).

The sampling frame consisted of the anagraphic records of the whole population of Casteggio aged 20-69 years in $1987(n=2021$ males and 2032 females). They were listed by sex and age decade $(20-29 ; 30-39 ; 40-49 ; 50-59$; 60-69 years) and the sample was randomised within each age decade in both sexes (stratified sample by age and sex).

The response rate was $46 \%$ among females and $48 \%$ among males. This response rate should be considered good taking into consideration that the survey involved a large number of tests and was conducted on healthy adult people. The distribution of the final population is given in table I.

\section{PROCEDURE}

Each subject was interviewed by expert dietitians using a food frequency questionnaire to estimate food habits and nutrient intake. This method has been extensively used in studies of the relationship between diet and disease. ${ }^{45} \mathrm{We}$ preferred the interview to the self administered questionnaire, in order to limit the risk of total omission of some foods, even if it is impossible to avoid the inability of people to remember the correct frequency of servings. (This fact can cause an underestimation of nutrient intakes.)

During the interview, people were asked about their weekly consumption of food and beverages, special attention being given to the type of fat used in the preparation of meals and the specific nature of meat, cheese, and vegetables in order to gain precise information about nutrient intakes. Additional questions were asked about the frequency and type of any vitamin supplement or dietetic product used. The amount of the usual serving was determined by means of a book of food reference pictures. These pictures represent at least three or four different portion sizes for each food. The size of each portion was chosen taking into consideration the "average" intake for men and women, as reported in other studies and/or in common menus. Nutrient intake was calculated using food composition data obtained by chemical analysis in our laboratory ${ }^{6}$; when this was not possible data from the Italian food composition tables were used. ${ }^{7}$

The food frequency questionnaire was validated in a previous study estimating protein intake from urine nitrogen with the Mitch formula, and phosphorus intake from urine phosphate. ${ }^{8}$ The results of the evaluation of food 
Table I Age and sex distribution of the population tested. Data are numbers of participants

Table II Mean standard deviation, and percentile distribution of dietary intake.

Table III Mean standard deviation, and percentile distribution of blood variables.

\begin{tabular}{llllllll}
\hline & \multicolumn{7}{l}{ Age classes (years) } \\
\cline { 2 - 6 } & $20-29$ & $30-39$ & $40-49$ & $50-59$ & $60-69$ & Total \\
\hline Men & 16 & 35 & 48 & 46 & 21 & 166 \\
Women & 17 & 36 & 51 & 61 & 21 & 186 \\
Total & 33 & 71 & 99 & 107 & 42 & 352 \\
\hline
\end{tabular}

intake using the questionnaire and a three day weighing method have not yet been published; the correlation coefficient is 0.68 for energy $(p<0.001), 0.79$ for carbohydrates $(p<0.001)$, 0.51 for fat $(p<0.005), 0.53$ for fibre $(p<0.005)$, 0.84 for alcohol $(p<0.001), 0.57$ for retinol $(\mathrm{p}<0.001)$.

Height (to the nearest $\mathrm{cm}$ ) and weight (to the nearest $\mathrm{kg}$ ) were determined in indoor clothing without shoes, according to standard protocol. Body mass index was then calculated (weight/ height $^{2}, \mathrm{~kg} / \mathrm{m}^{2}$ ).

Systolic and diastolic arterial blood pressures were measured twice by trained observers using a mercury sphygmomanometer (ERKA 300) in a sitting position after a rest of at least five minutes; the mean of the two readings was used for analysis.

Blood specimens were taken from all the participants for lipid and apolipoprotein determination: total serum cholesterol by the CHOD-PAP method; high density lipoprotein and triglycerides using standard laboratory methods; apolipoprotein A-1 and B by a single radial immunodiffusion method.

The hypercholesterolaemic and atherogenic potential of diets consumed by the population tested was evaluated using the cholesterol/ saturated fat index $(\mathrm{CSI}):(1.01 \times \mathrm{g}$ saturated fat $)+(0.05 \times \mathrm{mg}$ cholesterol $) .{ }^{9}$

STATISTICAL ANALYSIS

Mean value, standard deviation, and percentile distribution were calculated according to sex and age for all the variables tested and for nutrient intake. Correlations among body mass index, total cholesterol, high density lipoprotein cholesterol, triglycerides, apolipoproteins A-1 and B, systolic and diastolic blood pressure, and dietary intakes were evaluated by simple regression analysis for sex ( $M$ and $F)$ and two age groups (20-39 and 40-59 years).

\section{Results}

Mean, standard deviation, and percentile distribution of dietary intake for men and women are shown in table II.

\section{PROTEIN AND ENERGY}

Compared to the Italian recommended daily allowance, our population's diet contained average energy but excess protein. The protein intake was higher than the recommended levels in about $80 \%$ of the people, the mean animal/ vegetable protein ratio being 1.7 in women and 1.4 in men.

\section{LIPIDS}

In relation to the 50th percentile, fat consumption was about $36 \%$ of the total energy intake in women and $30 \%$ in men; the polyunsaturated/saturated fatty acid ratio increased with age from 0.34 in women and men aged 20-29 years to 0.39 in women and 0.44 in men aged 60-69 years. At the 50th percentile the women's cholesterol intake was $267 \mathrm{mg} /$ day, the highest intake being in the 30-39 year decade (328 $\mathrm{mg}$ ); in men, the cholesterol intake was higher than $300 \mathrm{mg} /$ day for all the age groups considered.

The saturated fatty acid and cholesterol content of each diet was used to calculate CSI as an index of the hypercholesterolaemic and atherogenic potential of the diet. At the 50th percentile the

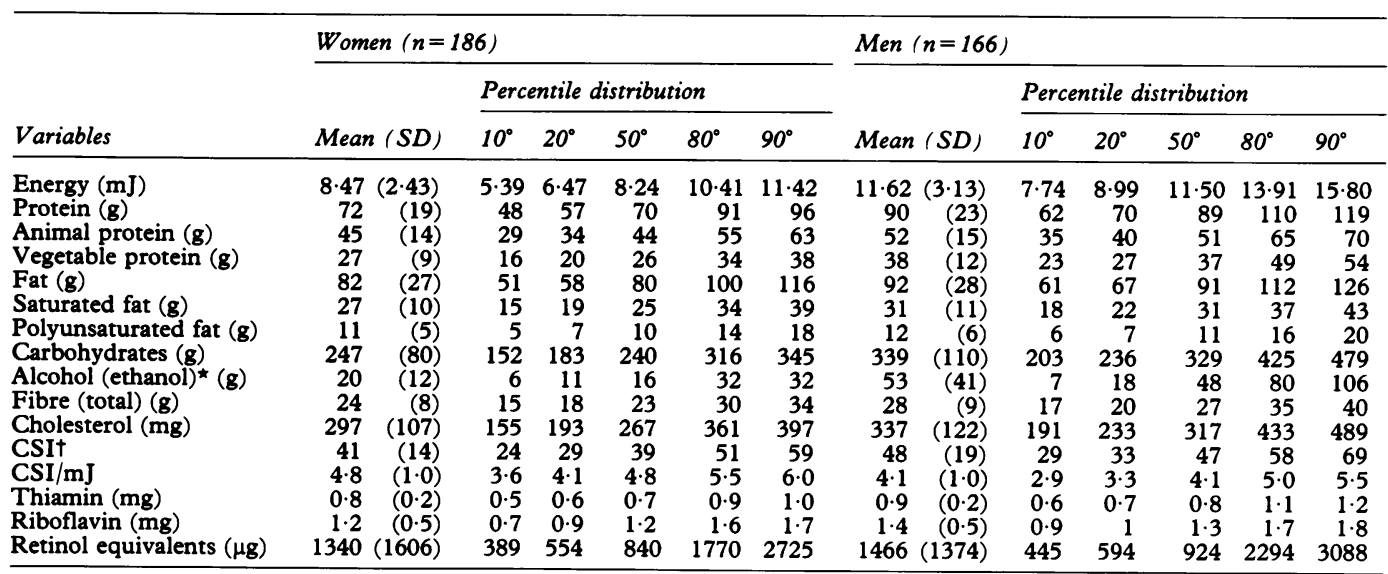

$\star$ Non-drinkers $(50 \%$ of women; $14.5 \%$ of men) are excluded from the distribution.

${ }^{\star N o n}$-drinkers $(50 \%$ of women; $14.5 \%$ of men $)$ are excly
tCSI $=(1.01 \times \mathrm{g}$ saturated fat $)+(0.05 \times \mathrm{mg} \text { cholesterol })^{6}$

\begin{tabular}{|c|c|c|c|c|c|c|c|c|c|c|c|c|}
\hline \multirow[b]{3}{*}{ Variables } & \multicolumn{6}{|c|}{ Women $(n=186)$} & \multicolumn{6}{|c|}{$\operatorname{Men}(n=166)$} \\
\hline & \multirow[b]{2}{*}{$\operatorname{Mean}(S D)$} & \multicolumn{5}{|c|}{ Percentile distribution } & \multirow[b]{2}{*}{ Mean (SD) } & \multicolumn{5}{|c|}{ Percentile distribution } \\
\hline & & $10^{\circ}$ & $20^{\circ}$ & $50^{\circ}$ & $80^{\circ}$ & $90^{\circ}$ & & $10^{\circ}$ & $20^{\circ}$ & $50^{\circ}$ & $80^{\circ}$ & $90^{\circ}$ \\
\hline $\begin{array}{l}\text { Apo A-1 (mg/dl) } \\
\text { Apo B (mg/dl) } \\
\text { Cholesterol (mg/dl) } \\
\text { HDL cholesterol }(\mathrm{mg} / \mathrm{dl}) \\
\text { Triglycerides (mg/dl) } \\
\text { Systolic BP (mg Hg) } \\
\text { Diastolic BP }(\mathrm{mm} \mathrm{Hg}) \\
\text { BMI }\left(\mathrm{kg} / \mathrm{m}^{2}\right) \\
\end{array}$ & $\begin{array}{r}138(18) \\
106(20) \\
226(41) \\
51(10) \\
96(68) \\
133(22) \\
82(12) \\
26(5)\end{array}$ & $\begin{array}{r}115 \\
79 \\
180 \\
40 \\
47 \\
88 \\
68 \\
20 \\
\end{array}$ & $\begin{array}{r}123 \\
88 \\
191 \\
42 \\
52 \\
113 \\
70 \\
22 \\
\end{array}$ & $\begin{array}{r}136 \\
103 \\
222 \\
50 \\
80 \\
129 \\
81 \\
24 \\
\end{array}$ & $\begin{array}{r}155 \\
122 \\
261 \\
60 \\
111 \\
154 \\
92 \\
29 \\
\end{array}$ & $\begin{array}{r}159 \\
133 \\
281 \\
66 \\
163 \\
163 \\
98 \\
32 \\
\end{array}$ & $\begin{array}{r}129(14) \\
113(22) \\
224(42) \\
46(10) \\
119(89) \\
132(17) \\
84(9) \\
26(3) \\
\end{array}$ & $\begin{array}{r}112 \\
88 \\
174 \\
35 \\
49 \\
112 \\
72 \\
22\end{array}$ & $\begin{array}{r}118 \\
98 \\
188 \\
38 \\
62 \\
117 \\
78 \\
23\end{array}$ & $\begin{array}{r}128 \\
112 \\
220 \\
46 \\
96 \\
130 \\
84 \\
26 \\
\end{array}$ & $\begin{array}{r}142 \\
128 \\
258 \\
54 \\
156 \\
144 \\
90 \\
29\end{array}$ & $\begin{array}{r}148 \\
146 \\
279 \\
59 \\
208 \\
157 \\
97 \\
30\end{array}$ \\
\hline
\end{tabular}

$\mathrm{Apo}=$ apolipoprotein; $\mathrm{HDL}=$ high density lipoprotein; $\mathrm{BP}=$ blood pressure; $\mathrm{BMI}=$ body mass index 
CSI per mJ was about 4.8 in all the women's age groups and between 4.8 (20-29 years) and 3.8 (60-69 years) in the men.

\section{CARBOHYDRATES}

Carbohydrates represented only about $45 \%$ of the energy consumption.

\section{ALCOHOL}

The percentile distribution of alcohol intake reported in table II refers only to drinkers (93 women and 143 men). It was found that $50 \%$ of the women did not drink, while $10 \%$ consumed more than $30 \mathrm{~g}$. In the men the consumption of alcohol greatly increased with age and was more than $50 \mathrm{~g}$ in about $40 \%$. It is interesting to note that in the first group (20-29 years) $50 \%$ of the men tested did not drink or drank little alcohol (less than $10 \mathrm{~g} /$ day); in the 60-69 year group this was true for only $20 \%$ of men.

\section{VITAMINS}

In women the mean values of thiamin and riboflavin intake were respectively $11 \%$ and $8 \%$ lower than recommended but the percentile distribution indicates that only $20 \%$ and $40 \%$ of the women consumed, respectively, thiamin and riboflavin in amounts comparable to or higher than the recommended values. The situation for the men was worse as only $10 \%$ had thiamin and riboflavin intakes higher than those recommended, thus indicating that their vitamin nutritional status could be more inadequate than that of the women. For vitamin A the situation is different, the intake being more than adequate in about $70 \%$ of the population. With regard to these data it is important to note that vitamin intake via food has been calculated using food composition data obtained by chemical analyses carried out in our laboratory on cooked foods ${ }^{6}$; thus cooking and storage losses are accounted for.
FIBRE

Some epidemiological studies carried out on different populations have shown that the dietary intake of fibre is inversely related to coronary heart disease. ${ }^{10}{ }^{11}$ Morris et al ${ }^{12}$ found that a high fibre intake protects against coronary artery disease, independently of other nutrients and other risk factors. The median fibre intake of the population we tested, $23 \mathrm{~g} /$ day in women and 27 $\mathrm{g} /$ day in men, was lower than the value of $30 \mathrm{~g} /$ day recommended by the National Advisory Committee on Nutrition Education proposals for nutritional guidelines for health education in Britain for the prevention of intestinal diseases, ${ }^{13}$ but is higher than the intake commonly found in western populations, corresponding to about 20 g/day.

\section{BLOOD MEASUREMENTS}

Mean, standard deviation, and percentile distribution of some blood variables are given in table III.

The percentile distribution of blood cholesterol levels was similar in women and men while high density lipoprotein cholesterol was only slightly higher in women. The 50th percentile value for male total cholesterol was about $200 \mathrm{mg} / \mathrm{dl}$ up to 40 years of age, it then increased to $230 \mathrm{mg} / \mathrm{dl}$ to 50 years, falling to $220 \mathrm{mg} / \mathrm{dl}$ in the oldest age groups. In women there was a continuous increase from $182 \mathrm{mg} / \mathrm{dl}$ in the first decade considered (20-29 years) to $253 \mathrm{mg} / \mathrm{dl}$ in the $60-69$ decade.

Triglycerides show a similar trend although they were lower than in other Italian groups of the same age. In men the highest values were present between ages 40 and 49 years (50th percentile value $=99 \mathrm{mg} / \mathrm{dl}$ ) while in women values increased with age (from 52 to $91 \mathrm{mg} / \mathrm{dl}$ ).

The 50th percentile value for the apolipoprotein Al level in men was $152 \mathrm{mg} / \mathrm{dl}$; apolipoprotein $B$ was $125 \mathrm{mg} / \mathrm{dl}$ and increased

Table IV Regression coefficients between blood variables and dietary intake of women.

\begin{tabular}{|c|c|c|c|c|c|c|c|c|c|c|c|c|c|c|}
\hline & \multicolumn{2}{|c|}{ Total cholesterol } & \multicolumn{2}{|c|}{ HDL cholesterol } & \multicolumn{2}{|c|}{ Triglycerides } & \multicolumn{2}{|l|}{ Apo $A-1$} & \multicolumn{2}{|l|}{$A p o B$} & \multicolumn{2}{|c|}{ Systolic pressure } & \multicolumn{2}{|c|}{ Diastolic pressure } \\
\hline & $A$ & $B$ & $A$ & $B$ & $A$ & $B$ & $A$ & $B$ & $A$ & $B$ & $A$ & $B$ & $A$ & $B$ \\
\hline $\begin{array}{l}\text { Energy } \\
\text { Total fat } \\
\text { Saturated fat }\end{array}$ & $\begin{array}{l}0 \cdot 224 \\
0 \cdot 306^{\star} \\
0 \cdot 394 \dagger\end{array}$ & $\begin{array}{r}-0.076 \\
0.025 \\
0.059\end{array}$ & $\begin{array}{l}0 \cdot 060 \\
0 \cdot 050 \\
0 \cdot 148\end{array}$ & & $\begin{array}{l}0 \cdot 196 \\
0 \cdot 203 \\
0 \cdot 213\end{array}$ & & $\begin{array}{l}0 \cdot 124 \\
0 \cdot 159 \\
0 \cdot 231\end{array}$ & $\begin{array}{l}-0.097 \\
-0.125 \\
-0.128\end{array}$ & $\begin{array}{l}0 \cdot 207 \\
0 \cdot 317^{\star} \\
0.361 \dagger\end{array}$ & $\begin{array}{r}-0.038 \\
0.075 \\
0.087\end{array}$ & $\begin{array}{r}-0.001 \\
0.056 \\
0.095\end{array}$ & $\begin{array}{l}-0.181^{\star} \\
-0.128 \\
-0.059\end{array}$ & $\begin{array}{l}-0.124 \\
-0.100 \\
-0.020\end{array}$ & $\begin{array}{l}-0.156 \\
-0.076 \\
-0.005\end{array}$ \\
\hline $\begin{array}{l}\text { Polyunsaturated } \\
\text { fat } \\
\text { Animal fat } \\
\text { Vegetable fat } \\
\text { Cholesterol } \\
\text { Fibre } \\
\text { Alcohol } \\
\text { BMI }\end{array}$ & $\begin{array}{l}0.184 \\
0.312^{\star} \\
0.187 \\
0.361 \dagger \\
0.065 \\
-0.290 \\
0.108\end{array}$ & $\begin{array}{r}0.002 \\
0.060 \\
-0.036 \\
-0.011 \\
-0.126 \\
0.073 \\
0.142\end{array}$ & $\begin{array}{r}0.029 \\
0.162 \\
-0.045 \\
0.072 \\
0.067 \\
0.009 \\
-0.273\end{array}$ & $\begin{array}{c}-0.134 \\
0.026 \\
-0.138 \\
-0.228^{\star} \\
-0.063 \\
0.195^{\star} \\
-0.37{ }^{\star}\end{array}$ & $\begin{array}{r}0.233 \\
0.175 \\
0.145 \\
0.222 \\
-0.016 \\
0.019 \\
0.226\end{array}$ & $\begin{array}{r}0.122 \\
-0.093 \\
0.034 \\
-0.038 \\
-0.109 \\
-0.110 \\
0.200^{\star}\end{array}$ & $\begin{array}{l}0.236 \\
0.127 \\
0.121^{\star} \\
0.138 \\
-0.064 \\
0.021 \\
-0.193\end{array}$ & $\begin{array}{c}-0.214 \\
-0.063 \\
-0.154 \\
-0.271 \dagger \\
-0.123 \\
0.204^{\star} \\
-0.249 \dagger\end{array}$ & $\begin{array}{c}0.238 \\
0.329^{\star} \\
0 \cdot 188 \\
0.354 \dagger \\
0.073 \\
-0.285^{\star} \\
0.168\end{array}$ & $\begin{array}{r}0.116 \\
0.057 \\
0.071 \\
0.056 \\
-0.066 \\
0.012 \\
0.351 \dagger\end{array}$ & $\begin{array}{r}0.218 \\
0 \cdot 119 \\
-0.008 \\
-0.009 \\
0 \cdot 184 \\
-0 \cdot 151 \\
0.306^{\star}\end{array}$ & $\begin{array}{c}-0.059 \\
-0.054 \\
-0.174 \\
0.107 \\
-0.231 \dagger \\
0.133 \\
0.505 \dagger\end{array}$ & $\begin{array}{c}-0.033 \\
0.050 \\
-0.164 \\
-0.091 \\
0.031 \\
-0.156 \\
0.385 \dagger\end{array}$ & $\begin{array}{c}-0.013 \\
-0.017 \\
-0.120 \\
0.146 \\
-0.189 \star \\
0.054 \\
0.582 \dagger\end{array}$ \\
\hline
\end{tabular}

$A=$ age range $20-39$ years; $B=$ age range $40-59$ years

$\mathrm{HDL}=$ high density lipoprotein; $\mathrm{Apo}=$ apolipoprotein; $\mathrm{BMI}=$ body mass index ${ }_{\star \mathrm{p}}^{\mathrm{H}}<0.05 ; \mathrm{tp}<0.001$

Table $V$ Regression coefficients between blood variables and dietary intake of men.

\begin{tabular}{|c|c|c|c|c|c|c|c|c|c|c|c|c|c|c|}
\hline & \multicolumn{2}{|c|}{ Total cholesterol } & \multicolumn{2}{|c|}{ HDL cholesterol } & \multicolumn{2}{|c|}{ Triglycerides } & \multicolumn{2}{|l|}{ Apo $A-1$} & \multicolumn{2}{|l|}{ Apo B } & \multicolumn{2}{|c|}{ Systolic pressure } & \multicolumn{2}{|c|}{ Diastolic pressure } \\
\hline & $A$ & $B$ & $A$ & $\boldsymbol{B}$ & $A$ & $B$ & $A$ & $B$ & $A$ & $B$ & $A$ & $B$ & $A$ & $B$ \\
\hline $\begin{array}{l}\text { Energy } \\
\text { Total fat } \\
\text { Saturated fat }\end{array}$ & $\begin{array}{l}0 \cdot 227 \\
0 \cdot 139 \\
0 \cdot 121\end{array}$ & $\begin{array}{l}-0.038 \\
-0.061 \\
-0.058\end{array}$ & $\begin{array}{l}-0.202 \\
-0.406 \dagger \\
-0.376 \dagger\end{array}$ & $\begin{array}{r}0.124 \\
-0.023 \\
0.047\end{array}$ & $\begin{array}{l}0 \cdot 261 \\
0 \cdot 208 \\
0 \cdot 142\end{array}$ & $\begin{array}{r}0.023 \\
0.034 \\
-0.061\end{array}$ & & & $\begin{array}{l}0 \cdot 309^{\star} \\
0 \cdot 275^{\star} \\
0 \cdot 196\end{array}$ & $\begin{array}{l}-0.082 \\
-0.079 \\
-0.112\end{array}$ & $\begin{array}{r}-0.014 \\
-0.075 \\
0.079\end{array}$ & $\begin{array}{l}-0.133 \\
-0.206^{\star} \\
-0 \cdot 223^{\star}\end{array}$ & $\begin{array}{l}-0.097 \\
-0.101 \\
-0.095\end{array}$ & $\begin{array}{l}-0.073 \\
-0 \cdot 119 \\
-0.109\end{array}$ \\
\hline $\begin{array}{l}\text { Polyunsaturated } \\
\text { fat } \\
\text { Animal fat } \\
\text { Vegetable fat } \\
\text { Cholesterol } \\
\text { Fibre } \\
\text { Alcohol } \\
\text { BMI }\end{array}$ & $\begin{array}{c}0.317^{\star} \\
0.193 \\
0.046 \\
0.155 \\
-0.057 \\
0.298^{\star} \\
0.334^{\star}\end{array}$ & $\begin{array}{r}-0.081 \\
-0.103 \\
-0.009 \\
-0.169 \\
-0.094 \\
0.108 \\
0.091\end{array}$ & $\begin{array}{c}-0.176 \\
-0.365 \dagger \\
0.322^{\star} \\
-0.301^{\star} \\
-0.254 \\
0.355 \dagger \\
-0.221\end{array}$ & $\begin{array}{r}0.044 \\
0.046 \\
-0.074 \\
0.103 \\
0.005 \\
0.152 \\
-0.282 \dagger\end{array}$ & $\begin{array}{c}0.179 \\
0.140 \\
0.209 \\
0.269 \\
0.174 \\
-0.067 \\
0.296^{\star}\end{array}$ & $\begin{array}{r}0.112 \\
-0.079 \\
0.120 \\
-0.107 \\
-0.014 \\
0.103 \\
0.225^{\star}\end{array}$ & $\begin{array}{c}-0.053 \\
-0.373 \dagger \\
-0.352^{\star} \\
-0.309^{\star} \\
-0.275^{\star} \\
0.503 \dagger \\
-0.185\end{array}$ & $\begin{array}{c}0.025 \\
0.076 \\
-0.047 \\
0.067 \\
0 \cdot 100 \\
0.210^{\star} \\
-0.289 \dagger\end{array}$ & $\begin{array}{l}0.415 \dagger \\
0.240 \\
0.226 \\
0.215 \\
0.062 \\
0.197 \\
0.331^{\star}\end{array}$ & $\begin{array}{c}-0.092 \\
-0.148 \\
0.000 \\
-0.182 \\
-0.060 \\
0.069 \\
0.232^{\star}\end{array}$ & $\begin{array}{r}-0.136 \\
0.001 \\
-0.125 \\
-0.086 \\
-0.035 \\
0.079 \\
0.399 \dagger\end{array}$ & $\begin{array}{c}-0.130 \\
-0.270 \dagger \\
-0.094 \\
-0.219 \star \\
0.091 \\
-0.125 \\
0.268 \dagger\end{array}$ & $\begin{array}{r}-0.034 \\
0.009 \\
-0.175 \\
-0.165 \\
-0.066 \\
0.048 \\
0.481 \dagger\end{array}$ & $\begin{array}{c}-0.030 \\
-0.149 \\
-0.060 \\
-0.206^{\star} \\
0.058 \\
-0.061 \\
0.330 \dagger\end{array}$ \\
\hline
\end{tabular}

$\begin{array}{lccc}0.334 & 0.091 & -0.221 & -0.282\end{array}$ 
slightly with age. Apolipoprotein A1 in women was higher than in men $(162 \mathrm{mg} / \mathrm{dl})$, while apolipoprotein B was $114 \mathrm{mg} / \mathrm{dl}$; both increased with age.

\section{BLOOD PRESSURE}

The systolic and diastolic pressures had similar values in men and women and increased with age (table III), especially in women, where the 50th percentile values were 109 and $72 \mathrm{~mm} \mathrm{Hg}$ in the 20-29 year decade and 156 and 91 in the 60-69 year decade.

BODY MASS INDEX

Data on body mass index are given in table III. The percentage of all women with an index higher than $24 \mathrm{~kg} / \mathrm{m}^{2}$ was $50 \%$, increasing from $10 \%$ in the first decade (20-29 years) to $60 \%$ in the last two decades (50-59 and 60-69 years). Men presented a similar picture, but the groups with the highest percentage of overweight people were the $40-49$ and $50-59$ year decades, $60 \%$ of the values being higher than $25 \mathrm{~kg} / \mathrm{m}^{2}$.

\section{CORRELATIONS WITH DIETARY INTAKE}

Regression coefficients calculated between blood variables and dietary intakes are reported in tables IV and V. Some interesting correlations were found in men aged 20-39 years. In this group the total energy consumption and the fat intake were positively related $(p<0.05)$ to apolipoprotein B levels. The alcohol intake in this group of men was positively correlated with both total blood cholesterol $(p<0.05)$ and high density lipoprotein cholesterol $(p<0.01)$. In women of the same age, total and saturated fat intake were positively correlated $(\mathrm{p}<0.05$ and 0.01 respectively) with total blood cholesterol and apolipoprotein B. These correlations were not present in the older groups.

Body mass index was positively correlated $(\mathrm{p}<0.01)$ with blood pressure, both in men and women. In older people there was also a positive correlation between body mass index, apolipoprotein B, and triglycerides, and an inverse correlation with apolipoprotein A-1 and high density lipoprotein cholesterol.

\section{Discussion}

Analysis of our results shows that the physiological reduction in basal metabolism with age is not followed by a decrease in energy intake in either the men or the women of the population tested. Consequently body mass index values higher than desired are present only at the 80th90 th percentile in the youngest decade of men and women, while they are present at the 60th percentile in the 30-39 year age groups and at the 40th percentile for the oldest decades. At the same time it should be noted that cholesterol and triglyceride levels, as well as systolic and diastolic pressures, increase with age. The correlations we found between body mass index and plasma cholesterol, triglycerides, apolipoprotein $\mathrm{B}$ and high density lipoprotein cholesterol, as well as blood pressure are in agreement with the findings of Jacobsen et $a l,{ }^{14}$ who showed that the standardised regression coefficients for these associations were higher than for the food items.

As regards the food composition of diets, it is important to emphasize that generally the women we interviewed answered the questions regarding the type of fat and the quality of the meat used for cooking in greater detail. This is ascribable to the living habits of the community we tested, where meals are generally prepared by women. The results obtained point out that for all the age groups the protein consumption is slightly higher in women than in men (medially $14^{\circ}{ }_{0}$ of total energy in women and $13 \%$ in men); furthermore animal protein intake is particularly high in women over 50 years of age (animal/vegetable protein $=1 \cdot 7$ ). Similarly, cholesterol intake is higher in women than in men $(32 \mathrm{~g} / \mathrm{mJ}$ and $28 \mathrm{~g} / \mathrm{mJ}$ respectively), as is total fat intake.

Alcohol consumption is almost negligible in women while in men it accounts for $13^{\circ}{ }_{0}$ of the total energy intake.

As regards the hypercholesterolaemic and atherogenic potential of the diet, depending on the saturated fatty acid and cholesterol content of the food, $50 \%$ of all the population tested had CSI values which indicated a risk of coronary heart disease. Referring to the relation reported by Connor et $a l^{9}$ between CSI $/ 1000 \mathrm{kcal}$ and the death rate for ischaemic heart disease in men aged 55-64 years, the male population we tested is comparable with the Italian average.

In spite of these reults the total blood cholesterol/high density lipoprotein cholesterol ratio of our population is within the acceptable range $(2 \cdot 0-6 \cdot 0)$ and is higher in men (4.9) than in women $(4 \cdot 4)$.

In conclusion, the values of the risk factors analysed are typical of a Western population; considering this, we think it should be useful to correct the dietary intake, especially as regards fat, cholesterol, and alcohol, for the prevention of coronary heart disease.

1 Kannnel WB, Castelli WP, Gordon T. Cholesterol in prediction of atherosclerotic disease. New perspectives based on the Framingham Study. Ann Intern Med 1979; 90 85-91.

2 Hulley SB, Rosenmann RH, Bawol RD, et al. Epidemiology as a guide to clinical decisions. The association between triglycerides and coronary heart disease. $N$ Engl $f \mathrm{Med}$ 1980; 302: 1383-9.

3 Kuske TT, Feldman EB. Hyperlipoproteinemia, atherosclerosis risk, and dietary management. Arch Intern Med 1987; 147: 357-60

4 Mullen BJ, Krantzler NJ, Grivetti LE, Schutz HG, Meiselman HL. Validity of a food frequency questionnaire for the determination of the individual food intake. $A m \mathcal{F}$ Clin Nutr 1984; 39: 136-43.

5 Bingham SA. The dietary assessment of individuals; methods, accuracy, new techniques and recommendations. Nutr Abs Rev (Ser A) 1987; 57: 705-42.

6 Porrini M, Ciappellano S, Simonetti P, Testolin G. Chemical composition of Italian cooked dishes. Int $\mathcal{f}$ Vit Nutr Res 1986; 56: 263-8.

7 Fidanza F, Versiglioni N. Tabelle di composizione degli alimenti. Naples, Italy: Iddelson, 1981.

8 Gentile MG, Fellin G, Manna G, D'Amico G, Ferrario L, Brunelli R. Educazione dietetica e controllo della compliance nel paziente con insufficienza renale cronica. In D'Amico G, Bazzi C, Colasanti G, eds. Attualita' D'Amico G, Bazzi C, Colasanti G, eds. Attualita'
nefrologiche e dialitiche. Milan, Italy: Wichtig, 1985: nefrologiche

9 Connor SL, Gustafson JR, Artaud-Wild SM, et al. The cholesterol/saturated-fat index: an indication of the hypercholesterolaemic and atherogenic potential of food. Lancet 1986; ii: 1229-32.

10 Kromhout D, Coulander CDL, Bosschieter EB. Dietary fibre and 10-year mortality from coronary heart disease, cancer and all causes. Lancet 1982; ii: 518-22.

11 Kushi LH, Lew RA, Stare FJ, et al. Diet and 20 year mortality from coronary heart disease. $N$ Engl $\mathcal{F}$ Med 1985; 312: 811-8.

12 Morris JN, Marr JW, Clayton DG. Diet and heart: a postscript. $B M \mathcal{F}$ 1977; ii: 1307-14.

13 National Advisory Committee on Nutrition Education Proposals for Nutritional Guidelines for Health Education in Britain. Lancet 1983; ii: 835-8.

14 Jacobsen BK, Thelle DG. The Tromso heart study: food habits, serum total cholesterol, HDL cholesterol and triglycerides. Am $¥$ Epidemiol 1987; 125: 622-30. 